\title{
REVISITA AL PLAN REGULADOR PARA MONTEVIDEO DE 1930 Invenciones y redes en torno al advenimiento del urbanismo científico en Uruguay
}

\author{
Lucio de Souza \\ Universidad de la República - Facultad de Arquitectura \\ E-mail: desouzalucio@gmail.com
}

\section{RESUMEN}

El Plan Regulador de Montevideo de 1930 ha sido repetidamente considerado en la historiografía uruguaya sobre la base de dos afirmaciones: como una propuesta fallida en el sentido de no haberse llevado a la práctica y como adscripto a la corriente de los CIAM. Si bien discutir la primera requiere de un cambio de mirada, la segunda es obviamente problemática por una cuestión de datación. La posibilidad de acceder a fuentes primarias con material nunca antes utilizado permite estudiar estos aspectos y plantear argumentaciones nuevas, que echan por tierra ambos asertos. Este artículo constituye un resumen de una investigación que tomó por foco el Plan Regulador aunque derivó en las redes que Mauricio Cravotto tejió durante sus años de formación y sus primeras décadas de trabajo profesional y académico en Urbanismo.

Palabras clave: Urbanismo científico, Cravotto, Plan Regulador, Montevideo

\section{ABSTRACT}

The Montevideo Regulatory Plan of 1930 has been repeatedly considered in Uruguayan historiography on the basis of two statements: as a failed proposal in the sense of not having been put into practice and as ascribed to the current of CIAM. While discussing the first requires a change of look, the second is obviously problematic as a matter of dating. The possibility of accessing primary sources with material never before used allows to study these aspects and to propose new arguments, which overturn both statements. This article is a summary of an investigation that focused on the Regulatory Plan although it derived in the networks that Mauricio Cravotto weaved during his formative years and his first decades of professional and academic work in Urbanism.

Key words: Scientific urbanism, Cravotto, Regulatory Plan, Montevideo 